\title{
Interview
}

\section{In conversation with Jozé Jancar}

\author{
Hugh Freeman interviewed Dr Jancar in Bristol in September 1992
}

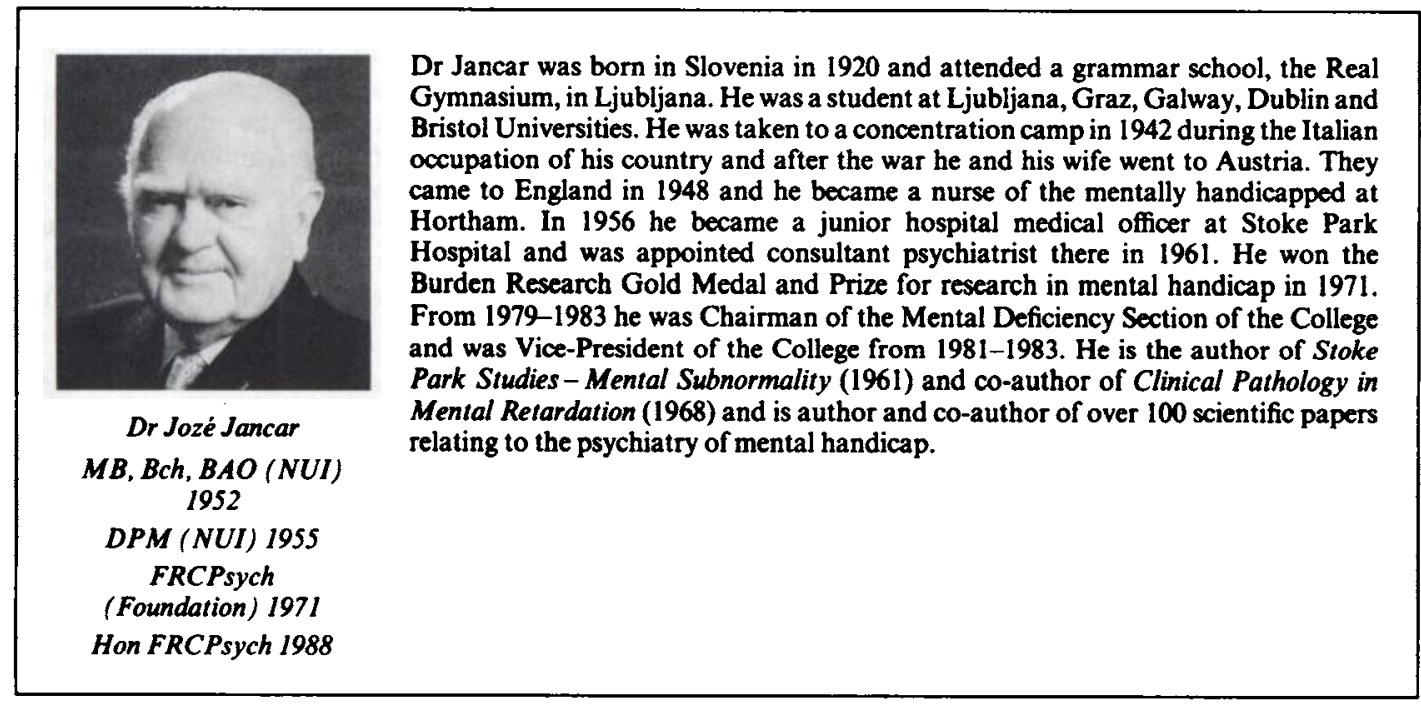

Your early life, I think, was very different from most of the people who have been interviewed previously for the Bulletin. Could you tell me something about it?

As you know, I was born in Slovenia. I had a very happy childhood and young adult life until 1941. I attended a grammar school, called the Real Gymnasium in Ljubljana. I travelled by train to the city every morning from my home in a village nearby. I earned my keep by helping other pupils who were not doing so well at school. I became head boy and received quite a few prizes, but the most exciting thing was when I was invited by King Peter, with the other $\mathbf{4 0}$ best pupils in Yugoslavia, to stay with him for a week in Belgrade, at his White Court.

Could you tell us a little more about your experience of going to the Palace in Belgrade, because this must be a very unusual experience for a psychiatrist?

When we were told that we were going, the grammar school where I attended made sure that we were smartly dressed; they gave us each a new suit and new shoes. Then, the Court sent a royal railway carriage to Ljubljana and five of us, with a Professor, went in this, attached to the Belgrade train. When we came to Zagreb, the Croatian contingent came on. As you know, Yugoslavia was then divided into eight provinces, and from each, the five best pupils had been selected. When we arrived at the special station in Belgrade on the royal train, we were taken to a hall, where each of us was fitted out with a Crombie overcoat. Each of us was then allocated to a boy from Belgrade, who was our own age and also one of the best pupils. It was an honour for him to receive one of us in his home. I was taken to the home of my host whose father owned an insecticide factory.

The next day, we went to the Court, where we met the King for the first time, and there I also met, for the first time, an English nanny. We each received a silver and gold medallion of Peter II. We visited the grave of King Peter's father in Oplenac, went to the theatre one day, to the Mint, and to the Airport to see the first German Junkers passenger plane. However, every night, we went to the Court to visit the King, where we were received and had a meal with the Marshall of the Court. The final day was the day of "Materice", which is a Serbian custom where the mother of the family has to give something to each 
member: it is like a Mother's Day in reverse. At the Palace, there was an international assembly of ambassadors to the Court, and it was a really beautiful evening, with Court music and presents from the Queen Mother. The Press had been with us all along, and Fox Movietone News were filming it all. Everybody had a few drinks, including me, and then, suddenly, the Marshall of the Court came along to our Professor. He said one of the Slovenes had to thank the King, as well as one of the Croats and one of the Serbs. Our Professor came over to me with a bunch of carnations, which is a Slovene flower and told me I had to give them to the King, and give the vote of thanks. I said I wasn't prepared for it, but he said I had to do it. The next day, I read my speech in the newspaper "Politika" and it seemed to be quite good, but I don't remember having given it! Next morning, we were saying goodbye to everybody, went to the train, and came home. It was a fantastic experience.

During the summer, I travelled a lot, learning about people and life; I cycled along the Dalmation Coast and in late summer I used to climb, as well as participating in athletics and winter sports. Unfortunately, when I matriculated and started medicine in Ljubljana, the War began in the spring of 1941, and we were occupied by the Italians. They let us study for about two years, and then the university was closed. We students were helping in various hospital departments; I was working in the Eye Department with the famous Professor Jevše, who had an international reputation; he was very encouraging to young people. Unfortunately, I was taken to a concentration camp in Gonars in 1942, and when Italy collapsed in 1943, the Germans occupied us. Once again, we were working with the Underground, helping in hospitals and treating people who had been involved in fighting against the Nazis, the Communists, and the Fascists.

How do you think your wartime experiences affected you later in life?

They taught me a lot about psychiatry, particularly in the concentration camp, when men's masks dropped, and you see each man as he really is. There were both University professors and road sweepers who were most helpful and real people; while others, without their masks, weren't really the people we had been seeing before. I spent a week in the death cell at Ljubljana. When I was arrested, they said that if any Italian was shot outside, they would take people from our cell to shoot them.

\section{You were hostages?}

Yes; it seems unbelievable, but we became stoically indifferent. They would come at 4 a.m. and call out names; these people would be taken out, and we just put names on the wall and went to sleep. Everybody who walked out neither cried nor swore-just defiantly walked out.

When we were being taken to the camp, they chained us together and put us in cattle trucks. We sang on our way to a concentration camp because we were out of the death cells. At St George's Station, near Gonars, we were thirsty and you know how the railway engines used to be fed with water; we put our hands out to catch some of this water, but the soldiers beat us back - wouldn't allow it. When we were walking towards the camp, people spat at us, and called us "Banditi". Yet, two years ago, I went to visit Gonars and I met the people there; they were so nice! We went to see the memorial to the people who died in camp and it is very well kept. I said to myself, how can man be so incited, for religion, for politics, or for nationality to do such cruel things? This was a great school of experience for me - one which I don't want anybody to repeat or go through, but I learnt a lot from it.

I believe that when you got out of the concentration camp at Gonars it was through the intervention of the Vatican. Is that right?

That is correct. Our Bishop from Ljubljana intervened through the Vatican to release the Slovene students, and pressure was brought on the Duce-Mussolini, and we got free.

\section{What happened next?}

At the end of the War, I went to Austria as an anticommunist refugee; where we were in camps, hoping that one day, we would be able to restart our studies. Unfortunately, the three Austrian Universities were in the wrong places: Innsbruck was under the French and Vienna and Graz under the Russians, so we had no hope of going to any of these.

\section{How did you manage to continue your studies?}

We had a great friend, John Corellis, who was working for UNRRA, and with his help, I was able to go illegally across the Dolomites to Padua, in August, 1945, but if I had been caught, I would have had to deny that we knew each other, or we would both have been in serious trouble. There, I met a Jesuit priest, whom I knew from Ljubljana, and I asked him if he would arrange an interview with the Rector of the University. I brought with me all I had salvaged, which were my University documents. He was a very charming man, and asked me what kind of curriculum we had had. When I told him that we had been occupied by the Italians, he said this curriculum was according to Italian law, and he smiled and said, "Right, I will accept you, and your wife and sister", but $I$ added that there were about 80 others. He 
replied, "All right, anyone who can produce a document from Ljubljana University will be accepted, providing they find their own money and accommodation". However, when I came back, the Russians had left Graz. It was much easier for us to study there because, Slovenia being such a small nation, we couldn't produce our own medical textbooks, and so we used German ones. It was terribly difficult to find anywhere to stay there, because there were thousands and thousands of refugees. I met Captain Ryder, who was chief of that sector for UNRRA, and he was very sympathetic. We went round and round Graz, to see if there was any place that could accommodate students, and found the "Keppler Schule", an empty grammar school, and we moved into it just before Christmas. There were some difficulties in the acceptance of some students because their documents were missing, and denazification was taking place. Luckily, I had documents stating that I was in the Gonars concentration camp, which helped, and that I was representing the Slovene students in Graz. Also, the Dean was of Slovene origin, and when we were on our own, he started to talk to me in our language, which was a great relief to me, and he was then very helpful. Soon after, we were moved into ex-German barracks, and were able to start studying, but life was hard. The first Christmas, we had only about 600 calories per day-a bit of soup with cabbage in it. Then a young lady came along - Iris Murdoch, a student herself. She was deputy director in the refugee camp, and we became very friendly; she is the godmother to my daughter and we are regularly in touch.

When I was in the final year, we had to do three weeks' residency in the neuropsychiatric department. The regular Professor had left through denazification, and they had recalled Professor De Gasperi, who was nearly 90 years of age. He was a contemporary of Adler, Jung, and Freud, but didn't belong to any of these three schools; he was independent. He said to us, "Psychiatry has a great future, providing you remain a doctor first, then a neuropsychiatrist. You have to examine each patient carefully because he has both a mind and a body, and you have to know which is affecting which". He was a really excellent lecturer, and I got so involved there and then, I decided to do psychiatry.

\section{When did you come to England?}

In 1948. We landed in West Wrating, near Cambridge and again Iris Murdoch was there as an undergraduate and she was very anxious that I should restart my medical studies. She took me to London to meet the Duchess of Atholl. I was very impressed to meet a Duchess for the first time; she spoke very good German, as well as French. Of course, I didn't have any English then. She said, "If you go away for a year somewhere to learn English, then we will be able to get a place for you either at Oxford or Cambridge". But I had come to England as a European Voluntary Worker, and there were only two places to go - either the mines or agriculture. I had to get out of those, though, if I was going to be able to continue medicine. One day an ex-Indian Army Sergeant Major came along, looking for someone to act as a male nurse in the YMCA Camp at Gloucester. I went there but there was really nothing to do, because they were all healthy people. They spoke every language from Europe except English, so I didn't learn any English, and I was getting quite frustrated.

I went into Gloucester one day, looking for a Catholic Church, hoping that somebody would know some language other than English. There was in fact a young priest who spoke Italian, and I asked him if I could get a job as a nurse in Gloucester. He said, "No, it is impossible", but he added, "I know a doctor near Bristol who is in charge of mentally handicapped people; would you like to work with them?". I said of course I would, because I wanted to do psychiatry. One day he collected me, and we went to see Dr Lyons at Hortham Hospital near Bristol, where he was the medical superintendent. This was the longest interview I have had in my career; it took nearly three hours. What he wanted to know was all about the War and what was happening in Europe; his wife knew a bit of German and the priest translated into Italian. Then he said, "I'll take you, providing that you don't wear the clothes you're wearing now" - because I went in my best suit - "that you are kind to the patients, and that you learn the English measures of medicine". These were the three conditions, and I was appointed to the highest possible grade, which was nursing assistant Grade I.

When we finished the interview, I asked him if he could also give a job to my wife. He asked, "Does she speak better English than you?". I said she did; she had learnt English in Graz, when she was a medical student. He accepted us. When I had been there for over a year, he called me into the office one day and said, "Now, you are finished here", and I was worried because I thought I had got the sack. "No", he said "you are going to be all right. You have learnt enough about mental handicap, but you will need a lot of terminology in English and Latin, so you must go to a general hospital". I went to BRI where I worked for over a year. I was rotated through every department, on both day and night duty, so that I had really great experience. I came to think that every medical student should have at least six months working as a nurse. When I became a doctor, I was able to ask nurses what I knew they could do and also criticise what I knew they were doing wrong.

Meanwhile, I wrote for admission to all Universities in England and Ireland; Bristol were willing to accept me, but I would have had to wait two years, 
because there were so many ex-servicemen, who had priority. However, I got very friendly with Professor Darling, who was in charge of the Dental Department, where I was nursing his patients. He said to me, "Would you like to do dentistry?", and I said I would; I had given up hope of doing medicine. He arranged an interview with the Professor from Newcastle. He accepted three years of my medical studies, with some extra time to qualify as a dentist.

Just then, a letter arrived from Professor Shea, who was Dean at Galway, and he offered me a place there. This was in January, and he said could I come as soon as possible, so that I wouldn't miss the term. Of course, I had to get a visa, and somebody had to give a guarantee for me. My wife and I were able to save some money, and with the help of friends, I managed to scrape together enough for the journey, and off I went to Ireland. There, the Rector asked me if I had means to support myself; I said yes, and I started, but it was very hard work. I remember reading Boyd for the first time, until about 3 o'clock in the morning; I had only got through about 20 pages. I realised how much English I lacked, so I went to Professor Kennedy and asked if I could do my exams in October, but he said I should do them in June. He told me he had studied in Heidelberg, and agreed that what I didn't know in English, I could do in German. We had to do philosophy and psychology, for which we had a Franciscan priest as Professor. I went to see him and told him about my difficulties with English. He said, "Are you a Latin scholar?". When I said, "Yes", he told me that what I didn't know in English, I could put in Latin, and this would be acceptable. This was another encouragement, but then came a crisis.

I remember so vividly that it was St Patrick's Day when I walked along Galway Bay wondering what to do next. My landlady was asking me for money, and I owed her two weeks' rent already. I thought the best thing would be for me to go to the Police and ask them to deport me. I didn't know anybody to borrow money from, and there seemed to be nothing else I could do. The next day, Iris Murdoch sent me $£ 100$, and this saw me through. At that time, all Galway students had to go for their final year to Dublin. This was really important to broaden our knowledge. There are three medical schools there and one examining body, each with their own professors and hospitals. We Galway people could travel round them, and we found out from the Dublin students which were the best in the various specialities. We made our own timetables, and the standards were very high; the schools were competing and the senior professors had all had experience in Europe, England or America. One course in particular I enjoyed very much was obstetrics and gynaecology, and I became very friendly with the Master. When I was leaving, he called me in and asked what my plans were when I qualified. I said, "I am going into psychiatry" and he said, "You are wasting your time". He offered to appoint me as Assistant Master, which at that time was a big job.

I thanked him, but let him know later on that I would stick to psychiatry.

At that time, there were quite a few hospitals in Dublin at which you could train for the DPM. I had my wife and daughter in Bristol, and I had to find a secure job, somewhere. I went to Grangegorman and other hospitals, but all the junior posts were booked. There were a lot of graduates from Dublin, and I had come from Galway. They advised me to try Ballinasloe, where I obtained a job. It was a 2,000-bed hospital and McCarthy was the superintendent; incidentally, he was also a co-editor of the Journal of Mental Science. He had worked in Canada with Banting and was a very brilliant man. When I was there for about a fortnight, he had a heart attack and died. His deputy was Jack Delaney, who was a great character, and a good psychiatrist.

A lot of people are saying today that mentally handicapped people should be having the same service as people with psychiatric disorders, but I saw the tragedy of this at Ballinasloe; severely mentally handicapped patients were placed with chronic schizophrenics, and the mildly subnormal with acute cases. They were badly treated by the patients, and nurses didn't know now to deal with them. I think this is the biggest mistake people can make if they are trying to develop 'generic' services; I witnessed that it doesn't work.

\section{They had no special services for the mentally handicapped?}

In 1950 they were poorly developed. However, I have visited and lectured in west of Ireland more recently, and they have developed very good services now.

After some time in Bellinasloe, I felt I was so tired of books that I wouldn't attempt any other qualifications; it had been such hard work, struggling to get my degree. However, a new medical superintendent was appointmented, Dr Shea - the brother of the Dean who had accepted me. He said, "Look, you have to get your DPM, or there is no future for you. You will always be junior". So I started again, but the requirement for the DPM then was that either you passed the lot, or if you failed any part, you failed it all. It was very hard, and there was no time off and no tutorials; I had to take my exams in my study leave.

\section{What happened after the DPM?}

I thought I was lacking in medical experience, and I went straight to the Mercers Hospital in Dublin, where I had been a student, and asked if I could have a place there. They offered me a post as a senior house 
physician, and I spent a very happy year there. After a few months, they called me to the Board Room, and I was quite worried as to whether I had done anything wrong. There was a colonel, ex-British army, who was the Chairman, and he said to me that they were watching my progress, and would I be happy to accept the post of Registrar, being in charge of the hospital? Nobody was actually running it then. There were students and junior doctors, and the senior staff were coming and going, but there was no organisation.

As Registrar, I organised both the students and the housemen, so that every consultant had a student and a junior doctor. Unexpectedly, I had a call from Dr Lyons in Bristol, who asked me to come and see him. I went, and he said, "If you want to succeed, you must come back to England and prove that you are capable of doing the job". So on 15 May 1956, I came for an interview at Stoke Park, and met a tall doctor called Alan Heaton-Ward, who was the medical superintendent. There were five people with the DPM for one JHMO position. After we had been interviewed, I was told I had got the job. Just before I left Ballinasloe, Dr Shea produced a book, and said, "Read this, and you will see where you are going; how lucky you are. It is a very famous hospital". It was the first Stoke Park Studies by Professor Berry so I was very apprehensive when I arrived to start my career at Stoke Park and in Bristol.

\section{What were your first impressions of England?}

When I came to Cambridge, I found the English countryside very flat. Of course, I had come from Slovenia, which is a mountainous country and the part I came from had nice valleys and fields. Also, they were talking in a language which I couldn't understand at all, though I knew German, French and Italian - as well as my own Slovene tongue. In England, I saw this cool, calm, Nordic type of a man or woman, who wouldn't give much away, but when he or she knew you, a real friendship would develop.

\section{What were your impressions of Ireland at first?}

Mixed feelings. I met people in England who had very little good to say about Ireland, and I met people there who had very little good to say about England. I began to see that both sides had some justification, but what impressed me was that there was a new generation of people in Ireland who did not want to talk about the troubles in the 1920s. They wanted to build a new Ireland. When I was at Mercers, which was a Protestant Hospital, there were many Catholic people in it; I am a Catholic myself, and they knew that, but nobody held that against me. At the same time, the Lord Mayor was a Jew. This tolerance is something we are all striving for. I was also impressed with the medical teachers in Ireland.
Shall we talk now about your early work in Stoke Park in the 1950s and 1960s?

I was very fortunate. Alan Heaton-Ward was really a very good colleague to me: he gave me freedom to develop my work. There was a very congenial atmosphere in the hospital. The medical superintendent, Matron, and Hospital Secretary were like a family. They knew every patient and every problem with the staff, and they were respected. I worked hard because I knew I had to prove myself, and we also used to work most Saturdays and weekends. I was also very fortunate that Professor Berry, who was 90 , was still in Bristol, as were Ronald Norman and Fraser Roberts. Dr Norman was an authority on neuropathology, and Fraser was an outstanding geneticist. They were both very kind to me and very encouraging. The other person who interested me very much was Grey Walter; like Golla, he was a very difficult man to get near to, but he was very helpful to me. I could go to him with any neurophysiological problem of the cases that I had. I was therefore very lucky to be in this milieu. From the psychiatric point of view, one of the greatest researchers at that time, was Professor Golla, at the Burden Institute.

Because of this grounding, I was able to move then towards other departments at Frenchay General Hospital for help. They became interested in the field of mental handicap; as I was asking things which they didn't know, they had to search for them, and became involved. There was Frank Lewis at Southmead Hospital, who started to study the chromosomes of our patients and became internationally renowned. I was, if you like, a catalyst to them, and we developed a service which I thought was secondto-none. My patients had priority before normal people for outside consultants. I think that it is a tragedy that anti-doctor, anti-psychiatric, and antihospital people have become so influential in this field. I was also very lucky to have two great tutors in Penrose, who was the greatest man in the country in mental handicap, and Dent, who came to see me often.

Could you say something about those two, Penrose and Dent?

At first, there was a little tension between Stoke Park and people from other centres, particularly Penrose. Here was the first multidisciplinary centre in the world for the subject, and he was a single-handed man. But when he realised what we were trying to do, he became very helpful. I had a huge correspondence with him about rare cases. He was a man for all seasons-calculus, or genetics, or even psychiatry; his Maudsley Lecture was an example of this, and the message was that mental handicap is the basis for future research in psychiatry. Dent was a biochemist, and was very anxious to find out more about this 
aspect of mental handicap. He examined hundreds of specimens from our patients.

\section{How were you involved in the development of services?}

In the 1970s, when there were various enquiries up and down the country about bad buildings and overcrowding in mental handicap hospitals, HeatonWard and myself were telling Ministers that we could not provide a good service if we didn't have money and facilities. However, the question of community care was creeping in already, and we had great difficulty in persuading the Department to give us permission to pull down old buildings and create small units. We persevered and eventually succeeded; we totally rebuilt both Purdown and Stoke Park Hospitals. What we achieved were specialised units for spastics, for the blind, for psychotics, and for the elderly; the last one was the first purpose-built unit for the elderly handicapped, which is an important issue at the moment. We also provided a unit for disturbed patients and an assessment unit. At case conferences in the community, we noticed that certain patients needed further assessment so we admitted them to this special unit, where all the professionals involved, both from within the hospital and outside, could be called in to make their contribution.

We also opened two clinics in Bristol and one in Gloucester where parents and other relatives could come with patients, and we were able to help and advise them. I feel whatever the future holds, we should never forget that in our service, the hospital is part of the community. Community care is great, providing that you give people the same quality of service as we gave.

\section{Tell me about your work for the College.}

Those were very interesting times. I was groomed for Chairmanship of the Mental Handicap Section by two old friends, Alec Shapiro and Alan HeatonWard, who were Secretary and Chairman. They planned for Valerie Cowie and myself to follow in their footsteps, and we did. What was exciting in the RMPA time was the battle to improve the Section for Mental Handicap - what was then called 'mental deficiency' - and support for this did not come either from the Department or from the RMPA itself. It was difficult, but we had help with good leadership, particularly from Alec Shapiro, though he was too strong-willed for some people.

\section{He once described me as a "self-appointed pseudo- expert", in a letter to The Lancet, because I had expressed some views on mental handicap, but we afterwards became very friendly.}

Yes, he could be difficult, but he had a vision and he was the one who, with Harvey Stephens, an
American, created the International Association for the Scientific Study of Mental Deficiency, which now has an international congress every three or four years. Its preliminary meeting was in London in 1961 , and then the organisation was formed in Copenhagen four years later. It now awards a special Stephens \& Shapiro Prize.

My Chairmanship of the Section was at a very difficult period-one of the hardest times at the College. I was at the same time, Vice-President. The President, Ken Rawnsley, was very ill, Gerald Timbury, the Registrar, had a stroke, and Natalie Cobbing, the College Secretary, was failing in her health. There was the 1983 Mental Health Act and also the battle over Russian expulsion from the World Psychiatric Association, which was really spearheaded from the College. I used to go to see Ken Rawnsley in hospital, and he was very supportive. The junior Vice-President, Michael Gelder, and other senior members of the College were also very helpful.

The hardest was the battle over the Mental Health Act at that time; the anti-psychiatry and anti-hospital lobby was very much in the forefront. If it hadn't been for the College, we would have had a very poor Mental Health Act. Bob Bluglass was chairing the special sub-Committee; he was a tremendous help to the President, and did a lot of work behind the scenes, lobbying various MPs and Lords. The Department was also very helpful, in spite of being very severely pressurised, and I should mention two of their people here, Pamela Mason, their senior medical officer and, particularly for mental handicap, Rodney Wilkins. They came regularly to the College with new proposals and ideas and were constantly changing different parts of the Bill.

The first White Paper on amendment of the 1959 Act was quite reasonable, and mental handicap was recognised in it, but then suddenly, the feeling was strongly anti-medical and anti-hospital. The College then tried to restore something like the old Board of Control, and succeeded in this, although under a different name - the Mental Health Act Commission. But it was only through raising the issue of people who had suffered brain damage from head injuries that we were able to salvage something for mental handicap in the 1983 Act.

It was unfortunate that so much time and effort went into that legislation. when some fairly modest amendments to the $1959 \mathrm{Act}$ would have been much better. On another subject, what about your involvement in research?

I have never been a full-time researcher, I was a doctor first, a psychiatrist second, and a specialist in mental handicap third, yet I always felt that we need to record what ever we observe. Through systematic 
recording, all of us who are working in the field will accumulate information which will help future generations. In the last 20 years, I have been particularly interested in the problem of ageing. With the late Dr Carter, I analysed the changes in age of the mentally handicapped during the last 50 years. It was remarkable how many were living longer and nearing the longevity of the normal population. We need to know what kind of facilities we have and what type of disorders will be found, compared with those of normal people. This is a very exciting area and luckily, we have a lot of material from the past which can be used for comparison. We were the first to publish data on cancer in the mentally handicapped, with information on what particular types are more prevalent in different groups. When I was in Australia at the last ISSMD meeting recently, we had a symposium on ageing, and people from many countries presented papers on the subject. I am anxious that young psychiatrists coming into the field should be encouraged to join in this research effort.

\section{What about your activities outside psychiatry?}

I believe it is very important to join with the other specialities in medicine, and I was very proud when I was elected President of the Bristol MedicoChirurogical Society, as it is one of the oldest medical societies in this country.

\section{What date was it founded?}

In 1874. My presidential address was on the history of mental handicap in Bristol and Bath. In Bath, there are records of a hostel going back to the 14th century, kept by the monks.

I think it is very important that psychiatrists should not be isolated. They should be working with their medical colleagues. People often look upon psychiatrists as being something different, but when they realise that you are also a doctor and are interested in various aspects of medicine, they accept you. I have never felt a stranger among my colleagues and, similarly, when the new Medical History Association of Bristol was formed, I was invited to be one of the founder members.

\section{How was your time on the Mental Health Act Commission? We were both present at its first meeting, at Sunningdale, in 1983.}

As you know, the campaigns leading up to the 1983 Act were reflected in the Commission; some members of the Commission were anti-medical, anti-psychiatric, and anti-hospital. However, I was very fortunate that in my team there were people who were highly professional and experienced. We covered Wales, the West of England, and parts of Broadmoor, and I had a very happy four years with them. I believe we did some good for the patients, that we were Commissioners not 'Commissars', and that the staff also benefited. Very often, when we went back we were welcomed, which I thought was very encouraging. I am also pleased that we were able to take care of mental handicap patients. Thanks to Gillian Shepherd, who was our first Regional Chairman, and Shirley Turner who was the second Chairman, we were able to form a special team. We made quite a good impact in making sure that patients in mental handicap hospitals, not just the ones who were legally detained, were provided with the services needed. But on the whole, the Commission has become too cumbersome, and I believe the Scottish arrangement is much better. They appointed permanent staff, with very senior people, like the old Board of Control, and this was what the College really wanted.

\section{Can you tell me about your involvement with the $B M A$ ?}

On the whole, the BMA had very little time for psychiatry; they were so much involved in politics of their own. When I joined the Mental Health Group Committee, it was Professor Linford Rees who had invited me there, and also proposed me as viceChairman. I realised that they were anxious to learn about our problems. I was keen that we should help all the doctors from various groups who were dealing with mental illness, for whatever reason, and we should bring them all together, under the umbrella of the BMA. Before I retired as the Chairman, we succeeded in gaining a permanent member on the Council. The College should continue to strive to have a good liaison with the BMA. One notices with pleasure that two past presidents of the College became presidents of the BMA.

\section{Could you say something about your writing?}

The book, Clinical Pathology in Mental Retardation resulted from a combination of interests between two people - a pathologist and a psychiatrist. Bob Eastham and I often discussed common problems, and neither of us had a relevant book which would help us in what we needed to know. So we started to work together and to our surprise - this was in the 1960 s - so much seemed to be happening in this field; the more we researched, the more we found. The book came to fruition, and was very well received; it was translated into Italian.

\section{Has any new book appeared on the subject?}

There are now books on pure pathology and new ones on mental handicap, but no such combination as the one we created. 
What about other publications?

The College is very fortunate that Dr Blake Marsh left money for the lecture named after him. Many eminent people from the field of mental handicap have been the lecturers. When I was invited by the College to lecture, I felt very honoured, but also worried about what to produce. It had to be something original. I started to look at various skin disorders associated with mental handicap. I was very interested in how skin disorders could reflect on the development of the brain and mind, as well as in how certain pathogeneics reflect them and are diagnostic of the nature of disorders. The lecture was published in your Journal, and it is still often quoted now as a topic which had not been researched enough. The same is true of skin disorders in general psychiatry too.

What do you feel about present developments in mental handicap services?

We must never forget that there is nothing new under the sun, so we must look back to see who tried things before, where they tried them, and how they worked. One must never dismiss new ideas as being irrelevant, but must judge how much advantage or disadvantage there will be for the patients, for the staff, and for the society. If you look back over the last 50 years, you see so many people wanting to claim they have all the answers. Muti-professionalism is very important and what ever we are trying to do, we should share the same vision and the same experience.

A good example is the question of community care. In the 1900 s, the first President of the MPA who worked in mental handicap talked about the same problem. Our work at Stoke Park in the 1950 s aimed to provide as good a service outside as in hospitals. The Victorians built hospitals for those people who were on the streets and in workhouses. Of course, there were some bad hospitals, but we mustn't condemn them all and say, "All was bad yesterday and all is good today". We always tried to copy the Americans and Scandinavians, but we don't copy them now, when they are telling us what trouble they are in with non-institutional care. Many people don't realise how much families of mentally handicapped people suffer.
At the moment, there are about six different labels for mental handicap floating around the country, confusing parents, professionals and others. I have been through the use of several different labels in my career, but I have never seen one make any real difference to the patients and their families. The Department of Health has had to give in to yet another change. Even some chairs - and incidentally, we now have six chairs for mental handicap in this country - are being relabelled to make them more fashionable.

What do you feel now about your native country?

I was born in a beautiful part of the world. We had our 'Peasant Revolution' in the 18th century, when we became independent from feudal obligations to the aristocracy. We kept our history, language, and nationality intact throughout all occupations - by the Austrian monarchy and before. The people are industrious, and now they have eventually reached something we were always striving for-independence. When we were in Yugoslavia, we wanted to have a genuinely federal state. However, we Slovenes have no ethnic problems, with a river dividing us from Croatia and the Alps from Austria and from Italy. Culturally, we have one of the highest proportions of literate people and the highest rate of publication of books for a little nation of about two million. We have very good education, with excellent grammar schools and university departments. Our Professors have been educated in the capital cities of Europe. Slovenia had suffered heavy losses in 1991 during the attacks by the Yugoslav army but the people have survived, are working hard, and a new Slovenia is emerging.

Finally I would like to say that I have been here since 1948, and everybody knows that I am Slovene, a political refugee, a foreigner, but $I$ have never been treated as such. I obey the law of the land, I respect the nation, and people here respect me. I have never had any problems, either at work or elsewhere, from that point of view. I am grateful for what this country has given me and also for what I have learnt here. I also hope that I have given something back. 